\title{
Exploring the Link between Television Program Pacing and Aggression among Iranian Students
}

\author{
Reza Nazari ${ }^{1}$, Md Salleh Bin Hj Hassan ${ }^{2}$, Pooya Nazari ${ }^{3}$ \& Saadat Parhizkar ${ }^{4}{ }^{*}$ \\ ${ }^{1}$ Computer Science and Engineering and Information Technology Department, School of \\ Electrical and Computer Engineering, Shiraz University, Shiraz, Iran \\ ${ }^{2}$ Department of Communication, Faculty of Modern Languages and Communication, \\ University Putra Malaysia, Malaysia \\ ${ }^{3}$ Students Research Committee, Yasuj University of Medical Sciences, Yasuj, Iran \\ ${ }^{4}$ Social Determinants of Health Research Center, Yasuj University of Medical Sciences \\ (YUMS), Yasuj, Iran \\ *Corresponding author: Social Determinants of Health Research Center, Yasuj University of \\ Medical Sciences (YUMS), Yasuj, Iran. Tel: 98-743-322-0881. E-mail: \\ parhizkarsa@gmail.com
}

Received: January 9, 2019 Accepted: May 2, 2019 Published: July 5, 2019

doi:10.5296/jsr.v10i2.14200ＵRL: https://doi.org/10.5296/jsr.v10i2.14200

\begin{abstract}
This study designed to examine the relationship between television program pacing and aggressive behavior among primary school students in Iran. The study was conducted in two phases. The first phase consisted of a survey with 424 primary school students (aged 7-12 years) in the five provinces of Iran which were selected through a multi-stage random sampling of Iran. This survey investigated whether exposure to television program was related to children's use of media that explored using Buss - Perry standard questionnaire. The results revealed that $23 \%$ and $49 \%$ of the students displayed high and moderate aggression level respectively. A total of 22 programs were selected as the most favorite children's TV programs which were assigned to a technical content analysis known as pacing in the second phase of study. The findings of the study showed that the highest pacing index was attributed to Pokemon (67.08), while Fetileh ranked as the lowest pacing index program (23.86). The results also revealed that TV program pacing scores were significantly and positively associated with aggression level of primary school children $(\mathrm{p}<0.05)$. The results of this study suggested the need for further attention on children's television program production to protect them from antisocial behaviors.
\end{abstract}

Keywords: Aggression, Pacing, Television program, Violent behavior 


\section{Introduction}

Media violence has been a topic for public discussion since the 1920s when scholars tried to perceive the impacts of the motion pictures on children (Blumer, 1933; Anderson \& Hanson, 2009; Ferguson, 2015). With the growth of the television in the 1950s, the interest towards the effects of media violence has been increased (Liebert \& Sprafkin, 1988; Vande berg, Wenner, \& Gronbeck, 2004; José Martínez, Prieto, \& Farfán, 2006). In the decades that followed, social scientists have examined the relationships between television violence and juvenile delinquency (Daigle, Cullen, \& Wright, 2007; Reingle, Jennings, Maldonado-Molina, Piquero, \& Canino, 2011), desensitization (Anderson, et al., 2003; Murray, 2008) and fear (Kupchik \& Bracy, 2009). As Grimes and Bergen (2008) argue, undoubtedly television has affected us, particularly in the case of children. Aggression in childhood is considered as a serious problem, especially among children who display aggression at different times and contexts (Nazari et al., 2013; Bendersky, Bennett, \& Lewis, 2006) as they are more likely to display the future juvenile misdeed (Hinton, Sheperis, \& Sims 2003) and violent offending (Broidy, et al., 2003; Bendersky, Bennett \& Lewis, 2006). It is quite clear that children absorb every type of media that they have access to, from TV to computers, video games, print media, videotapes, and even to music. Researchers have established that there is an increase of aggressive behavior after being exposed to television or movie violence (Bandura, Ross \& Ross, 1963; Funk, Baldacci, Pasold, \& Baumgardner 2004; Savage \& Yancey, 2008; Moses, 2008). Children who watch more television and play violent video games are more likely to view violence and exhibit hostile attributional biases (Buchanan, Gentile, Nelson, Walsh, \& Hensel, 2002). Additional findings showed that physically aggressive children were possibly more than non-physically aggressive children to watch violent movies (Savage, 2008). Additionally, strong relations were showed by meta-analysis between exposure to media violence and both emotional and behavioral problems, especially aggressive feelings and actions (Anderson et al., 2003). 'Effects of media violence may be quite similar to the effects of real life violence, with research confirmation beginning to amass for links between media violence and increased psychopathology, increased enmity, aggression, and reduced empathy' (Anderson et al., 2003). According to Villani (2001), children and adolescents are specifically vulnerable to the television messages which affect their behaviors and perceptions. Most researchers conclude that children learn aggressive attitudes and behavior from violent media content (Emory \& Gridina, 2000) and a large number of studies have revealed that media violence has an impact on children's later aggression (Bensley \& Eenwyk, 2001; Wilson, et al., 2002). Media violence has appeared in many formats, from television programming and movies to video games and other interactive activities. Scholars believe that TV program pacing, i.e. how fast cuts are edited, is one of the most important factors affecting viewers' attitude and behavior (Zimmerman \& Christakis, 2007). Media studies have worked on how various kinds of media content (advertising, news, sports, violence, and so on.) impact people's attitudes, behaviors, emotions, knowledge, and perceptions (Nazari, Hasbullah, Parhizkar, Shirazi, \& Marioriad, 2009). In the past years, some studies have concentrated on how the media structural features such as cuts, camera techniques, light, edits, sound, voice changes, and so on change viewers' cognitive and emotional processes (Potter \& Callison, 2000; Lang, Schwartz, Chung, \& Lee, 2004; Potter \& Choi, 2006; Fox, Park, \& Lang, 2007). 
Recent researches (Lang, Bolls, Potter, \& Kawahara, 1999; Yoon, Bolls, \& Muehling, 1999; Lang, Zhou, Schwartz, Bolls, \& Potter, 2000; Bickham, Wright, \& Huston, 2001; Kang, Wright, \& Huston, 2006) have shown that production pacing has effects on attention, memory, attitudes, and behaviors that go beyond the influence of the message content. Production pacing is, therefore (along with the message content), a key feature that can influence a viewer in processing media messages.

Formal features like pace, movement, music, visual effects, voices, and sounds are proven to have effects on viewers' behaviors (Wright, et al., 1984). The content features such as emotion, erotic portrayals, humor, and violence are proven to affect viewers' attention and arousal.

In terms of theoretical perspective, the Social Cognitive Theory maintains its status as one major theory used to explain the influence of viewing violent programs on children's levels of aggression (Bandura, 1965) On the other hand, the Limited Capacity Theory serves as the other major theory in the present study which can explain the nature of TV program pacing influences on the students' aggressive behavior. The present study tries to add to the current body of literature by investigating the relationship between TV program pacing and the Iranian primary students' aggressive behavior which might be confirmed by these theories. Considering the undeniable importance of communication theories in transferring message to the audiences, the present study has close ties with social cognitive theory to cover the first phase and limited capacity theory to cover the second phase of the present study.

To the best of the researcher's knowledge and the available database, no research has explored the relationship between TV program pacing and aggressive behavior among children in Iran. So the purpose of this study was to explore the relationship between television program pacing and students' aggression level.

\section{Materials and Methods}

The current study was conducted in two phases: the first phase is consisted of a cross-sectional study among the Iranian primary school students on the basis of the TV programs preference among students and its relationship with their aggression level. Moreover, the second phase included a particular content analysis (known as pacing index) of the most popular TV programs among the primary school students and its relationship with their aggressive behavior.

This study obtained approval from the Islamic Republic of Iran Broadcasting (IRIB) which is a governmental organization. Written consent also was obtained from the parents before their children were recruited into the study.

\subsection{Phase I}

\subsubsection{Study Location}

The study was conducted in Iran. Iran is subdivided into thirty one provinces, each governed from a local centre, usually the largest local city, which is called the capital of that province. 
The provincial authority is headed by a governor-general, who is appointed by the minister of the interior subject to approval of the cabinet. The study was conducted in randomly selected five provinces from different geographical areas of country. The selected provinces were: Gilan, Hormozgan, Kurdistan, Yazd, and Markazi which are located in the North, South, West, East, and Central region of Iran respectively. In each province one urban as well as one rural area was selected randomly. Since, based on country's rule, there are separate schools for boys and girls, so in order to explore the relationship between TV viewing habits and aggressive behaviors in children, from each selected areas (rural and urban area of each selected province) two schools were selected randomly covering two genders, adding up to a total of 20 schools. The flow chart of the study is shown in Figure 1.

\subsubsection{Participants}

Four hundred twenty four primary students (grade one to five) enrolled to the present study. The participants were residing in five provinces of Iran in different geographical areas. Half of the students were male (50.5\%) and residing in urban area. The mean age ( \pm Standard Deviation) of children were $9.76 \pm 1.61$ years ranging from 7 to 12 years. The students' family size and birth rank were $4.36 \pm 1.34$ and $1.82 \pm 1.26$ respectively. The students' fathers and mothers mean age were $38.82 \pm 5.91$ and $34.28 \pm 5.54$ years respectively. The majority of students' father worked as nonprofessional employers $(52.1 \%)$ in their provinces and occupation of most their mothers were housewife (87.5\%). Most of the students' parents had finished primary school as their educational level ( $26.7 \%$ and $36.8 \%$ for fathers and mothers respectively).

\subsubsection{Instrument}

A structural questionnaire was used as data collection tool consisting of three sections as follow: a) respondent's socio-demographic information, b) television viewing habits and c) Buss - Perry's Aggression Questionnaire (AQ). Content validity of the questionnaire was ascertained by an expert panel, which comprised three mass communication specialists, an epidemiologist, an educational psychologist and a clinical psychologist with specialty in children behaviours. The Buss - Perry's Aggression Questionnaire (AQ) is a standardized questionnaire. It includes four subscales namely Physical Aggression, Verbal Aggression, Anger, and Hostility. The questionnaire consisted of 29 items and in a 5-point Likert format from 1 (extremely uncharacteristic of me) to 5 (extremely characteristic of me) (Gerevich, Bácskai, \& Czobor, 2007). However, the Buss - Perry's aggression questionnaire was validated and made norm base on the Iranian culture previously and consequently 4 items were deleted from the original questionnaire, and finally, a 25 item questionnaire was prepared. The trait aggression was measured by the total score of the AQ and scores of the subscales including Physical Aggression (items from 1 to 7), Verbal Aggression (items from 8 to 12), Anger (items from 13 to 17), and Hostility (items from 18 to 25) (Mohammadi, 2007; Samani, 2008). Aggression level of students is defined as Low Aggressive (percentile <25\% of aggression score); Moderate Aggression percentile (from 25\% to 75\%); and High Aggression (percentile $>75 \%$ of aggression score) (Buss \& Perry, 1992; Anderson \& Dill, 2000). Reliability (internal consistency) was assessed using Cronbach's alpha. The Cronbach's alpha coefficient was 0.94 for the 25 aggression questions indicating adequate reliability of the 


\section{Macrothink}

questionnaire (Nunnally, 1978). The questionnaire was pretested among 30 elementary students for checking the clarity of the items excluded from the study samples. The survey was administered in a quiet place at the students' home. Children were interviewed by trained interviewers by reading questions and answer choices, and allowed students to answer the questions. The required time for completion of each questionnaire was equal to 30 minutes. Upon the completion of the questionnaires, the children received a novelty pencil as an appreciation for their participation.

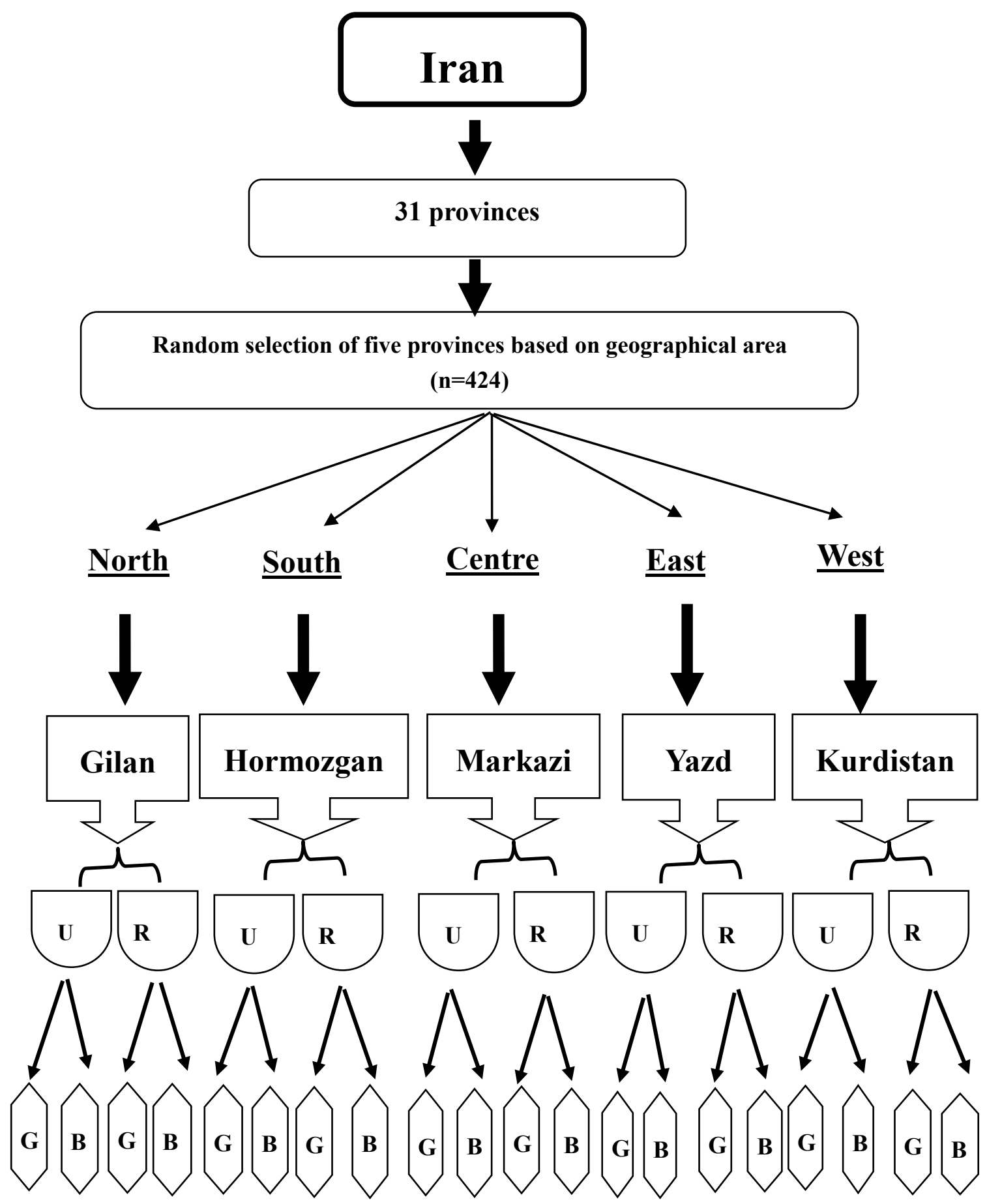

Figure 1. Flow Chart on Sample Selection

U: Urban - R: Rural - G: Girls' School - B: Boys' School 


\subsection{Phase II}

The second phase was aimed to determine the relationship between the most popular children TV program pacing and the level of aggressive behavior among the subjects. In order to achieve this, a particular content analysis (known as pacing index) was used to analyze 22 programs which were selected based on the results of the first phase and were assigned a pacing index derived from the following criteria: (a) frequency of camera cuts, (b) frequency of related scene changes, (c) frequency of unrelated scene changes, (d) frequency of auditory changes, (e) percentage of active motion, (f) percentage of active talking, and (g) percentage of active music.

\subsubsection{Measurement of Pacing}

The present study used the pacing index developed by McCollum and Bryant (2003). They developed it to fit the new perspective on children's television. In this study, the pacing index is a weighted index, in which many different things are measured, and then combined using specific weights suggested by McCollum and Bryant (2003) to create a single number. They indicate that most of the criticisms looking at children's television involve the frantic moving from one camera to another (or from one scene to another). In their study, McCollum and Bryant (2003) believe that such shifts provide the new information for the viewers to process, and therefore, $50 \%$ of their study's pacing index involved in cuts $(15 \%)$, related shifts $(15 \%)$, and unrelated shifts (20\%). In addition, they considered the next $20 \%$ was originated from movement on the screen as active motion (20\%). As an instance, a 60-sec camera shot, without any cuts, would typically give a slow pace, yet, if that camera was put on the front of a moving roller coaster, the viewer is provided with a great deal of activity. The final $30 \%$ comprises the amount of active talking (10\%), active music (10\%), and the number of auditory changes $(10 \%)$. Therefore, the following formula yielded each program pacing index: [(normalized percentage of unrelated shifts $) \times .20]+[$ (normalized percentage of related shifts $) \times .15]+$ $[($ normalized percentage of camera cuts $) \times .15]+[$ (percentage of active motion $) \times .20]+$ $[($ normalized percentage of auditory changes $) \times .10]+[$ (percentage of active music $) \times .10]+$ $[($ percentage of active talking $) \times .10]=$ pacing index. Table 1 demonstrates how the pacing index for Superman was derived.

Table 1. Determining the Pacing Index for Superman

\begin{tabular}{lllll}
\hline Criteria & $\begin{array}{l}\text { Frequency or } \\
\text { Percentage }\end{array}$ & Score & $\begin{array}{l}\text { Weight } \\
(\%)\end{array}$ & New Score \\
\hline Unrelated shifts & 0 Shifts & 0 (normalized) & 20 & 0 \\
Related shifts & 21 Shifts & 60 (normalized) & 15 & 9 \\
Camera cuts & 117 Cuts & 89.31 (normalized) & 15 & 13.39 \\
Auditory changes & 31 Changes & 48.43 (normalized) & 10 & 4.84 \\
Active motion & $72 \%$ & 72 & 20 & 14.4 \\
Active talking & $40 \%$ & 40 & 10 & 4 \\
Active music & $90 \%$ & 90 & 10 & 9 \\
Total Pacing Index & & & & 54.63 \\
\hline
\end{tabular}




\subsubsection{Unit of Analysis}

One episode was selected randomly from each of those favorite children's television series programs separately. Then, from each chosen episode, just 5 minutes was selected from the middle section. Similarly, other researchers also chose 5 minutes as the unit of analysis for pacing (McCollum \& Bryant, 2003; Macnamara, 2005).

Watching the selected episodes by the researcher revealed that they mostly began with slow pacing at the beginning; therefore, to have a conformity of decision, it was decided that the 5 -minute segment was chosen from the middle part of each episode for all 22 children's favorite television programs to have homogeneity of pacing rate. Based on the length of the episode, the middle section was found. For instance, if the length of the episode was 20 minutes, the middle section of this episode was determined to be 10 minutes after the starting time. Later, to select the 5-minute segment, the $21 / 2$ minutes before the 10 minutes and the $21 / 2$ minutes after the 10 minutes were selected. However, if any commercials interrupted the program show while examining it, the remaining time was added after the break. For example, if the 20 minutes children's television program was interrupted at $111 / 2$ minutes, the total measured segment time before the commercial was 4 minutes, it would be necessary to select 1 minute of the children's television program after the commercial was over. Consequently, 4 minutes before the commercial plus 1 minute after the commercial became 5 minutes.

\subsubsection{Reliability of Coding Procedures}

By using Premier software, an automated content-analysis facility, coding was carried out. Two coders including the researcher of the current study and another expert who was the director of television programs were placed in video editorial room. The coders used buttons that they pressed whenever they came across the measuring point which was introduced in the segment of the screening program. Before the actual coding, the segment was screened for each coder sufficiently to decide onset and offset marks for each point of interest. Prior to the coding of the programs, the coders watched the segments together and discussed possible areas of uncertainty. Conversation and discussion among the coders was permitted to eradicate the uncertain points. When the coders felt that they have learnt their assigned criteria in a segment, it was screened. Coding was carried out in real time, to permit duration as well as frequency measures for each dimension of pacing. The pilot tests were administered to analyze both the work of the coders and the coding scheme. Reliability was checked in two ways: test-retest comparisons of scoring by the same coder at different times (intracoder agreement) and comparisons of two independent scorers (intercoder agreement).

The Kappa (k) was used to assess the agreement between two coders whom have examined the same data and computed it based on the following equation:

$$
k=1-\frac{\operatorname{pr}(o)-p r(e)}{1-p r(e)}
$$

Where ' $\operatorname{Pr}(0)$ ' is the relative observed agreement among the coders, and ' $\operatorname{Pr}(\mathrm{e})$ ' is the probability agreement calculated based on the observed data and indicated the probability of each coder's randomly selected category. If there is a complete agreement between the coders, 
the $\mathrm{k}$ will be equal 1 , and the value will be less than or equal to 0 , if there is no agreement between observers, it will be concluded that they have selected the categories by chance (Cohen, 1960).

Intracoder reliability was conducted and the following Cohen's Kappas were yielded: related shifts, 0.875; unrelated shifts, 1.000; camera edits, 0.986; auditory changes, 0.974; active motion, 0.807; active talking, 0.843; and active music, 0.785. The mean Kappa was 0.895. Inter coder reliability checks were conducted and mean of Cohen's Kappas for each criteria were as follows: related shifts, 0.821; unrelated shifts, 1.000; camera edits, 0.864; auditory changes, 0.897; active motion, 0.834; active talking, 0.807; and active music, 0.736 . The grand mean for these inter coder Kappas was 0.851 which was indicated perfect reliability (Zegers et al. (2010).

\subsection{Data Analysis}

One- way ANOVA followed by Post Hoc test (Duncan), Spearman correlation analysis, Chi-Square analysis and linear regression analysis were performed for data analysis, using SPSS version 18. The level of significance for all statistics was set at $p<0.05$.

\section{Results}

Table 2. Demographic Profile of Students by Province

\begin{tabular}{|c|c|c|c|c|c|c|}
\hline \multirow[b]{2}{*}{ Characteristics } & \multicolumn{5}{|c|}{ Provinces } & \multirow[b]{2}{*}{$\begin{array}{l}\text { Total } \\
(\mathrm{n}=424) \\
\mathrm{f}(\%)\end{array}$} \\
\hline & $\begin{array}{l}\text { Gilan } \\
(\mathrm{n}=114) \\
\mathrm{f}(\%)\end{array}$ & $\begin{array}{l}\text { Markazi } \\
(\mathrm{n}=68) \\
\mathrm{f}(\%)\end{array}$ & $\begin{array}{l}\text { Yazd } \\
(\mathrm{n}=56) \\
\mathrm{f}(\%)\end{array}$ & $\begin{array}{l}\text { Hormozgan } \\
(\mathrm{n}=110) \\
\mathrm{f}(\%)\end{array}$ & $\begin{array}{l}\text { Kurdistan } \\
(\mathrm{n}=76) \\
\mathrm{f}(\%)\end{array}$ & \\
\hline \multicolumn{7}{|l|}{ Sex } \\
\hline Male & $56(49.10)$ & $37(54.4)$ & $27(48.2)$ & $50(45.5)$ & $44(57.9)$ & $214(50.47)$ \\
\hline Female & $58(50.90)$ & $31(45.60)$ & $29(51.8)$ & $60(54.5)$ & $32(42.1)$ & $210(49.53)$ \\
\hline \multicolumn{7}{|l|}{ Age } \\
\hline 7 & $17(14.9)$ & $7(10.3)$ & $10(17.9)$ & $8(7.3)$ & $4(5.3)$ & $46(10.84)$ \\
\hline 8 & $14(12.3)$ & $16(23.5)$ & 11(19.6) & $13(11.8)$ & $7(9.2)$ & $61(14.38)$ \\
\hline 9 & $21(18.4)$ & $9(13.2)$ & $8(14.3)$ & $23(20.9)$ & $10(13.2)$ & $71(16.74)$ \\
\hline 10 & 21(18.4) & $15(22.1)$ & $12(21.4)$ & $28(25.5)$ & $23(30.3)$ & $99(23.35)$ \\
\hline 11 & $14(12.3)$ & $8(11.8)$ & $11(19.61)$ & $17(15.5)$ & $18(23.7)$ & $68(16.03)$ \\
\hline 12 & $27(23.7)$ & $13(19.1)$ & $4(7.1)$ & 21(19.1) & $14(18.4)$ & $79(18.63)$ \\
\hline Mean \pm SD & $9.71 \pm 1.74$ & $9.58 \pm 1.65$ & $9.26 \pm 1.58$ & $9.87 \pm 1.50$ & $10.13 \pm 1.39$ & $9.75 \pm 1.60$ \\
\hline \multicolumn{7}{|l|}{ Grade } \\
\hline 1 & 21(18.4) & $13(19.1)$ & $10(17.9)$ & $9(8.2)$ & $4(5.3)$ & $57(13.44)$ \\
\hline 2 & $13(11.4)$ & $14(20.6)$ & $10(17.90$ & $14(12.7)$ & $10(13.2)$ & 61(14.38) \\
\hline 3 & $28(24.6)$ & $11(16.2)$ & $14(25)$ & $30(27.3)$ & $9(11.8)$ & $92(21.69)$ \\
\hline 4 & $25(21.9)$ & $14(20.6)$ & $9(16.10)$ & $31(28.2)$ & $19(25)$ & $98(23.11)$ \\
\hline 5 & $27(23.7)$ & $16(23.5)$ & $13(23.2$ & $26(23.6)$ & $34(44.7)$ & $116(27.36)$ \\
\hline \multicolumn{7}{|l|}{ GPA } \\
\hline $14-16$ & $3(2.63)$ & $5(7.35)$ & $2(3.570$ & 11(10) & $0.0(0.0)$ & $21(4.95)$ \\
\hline $16.01-18$ & $26(22.80)$ & $13(19.11)$ & $3(5.35)$ & $28(25.45)$ & $9(11.84)$ & $79(17.63)$ \\
\hline $18.01-20$ & $85(74.56)$ & $50(73.52)$ & $51(91.07)$ & $71(64.54)$ & $67(88.15)$ & $324(76.41)$ \\
\hline Mean \pm SD & $19.03 \pm 1.27$ & $18.78 \pm 1.43$ & $19.35 \pm 1.02$ & $18.59 \pm 1.53$ & $19.37 \pm 0.78$ & $18.98 \pm 1.31$ \\
\hline
\end{tabular}

GPA: Grade Point Average 


\section{I Macrothink}

Journal of Sociological Research

ISSN 1948-5468

2019, Vol. 10, No. 2

The participants were residing in five provinces of Iran in different geographical areas. Extremely half of the students were male (50.5\%) and residing in urban area. The mean age of children were $9.76 \pm 1.61$ years ranging from 7 to 12 years. Additional demographics revealed 57 first-graders (13.44\%), 61 second-graders (14.38\%), 92 third-graders (21.69\%), 98 fourth-graders (23.11\%), and 116 fifth-graders students $(27.36 \%)$ responded to the survey. The majority of the students (76.41\%) have given GPA ranged from 18.01 to 20 in their last study semester or year and the mean of their GPA was $18.98 \pm 1.31$ out of 20 . It revealed that the students mostly had a good achievement (Table 2).

This study explored the relationship between television program pacing and aggression level among the primary students. For identifying aggression level in students, referring to variables distribution, which did not meet the normal distribution assumption, so the level of aggression was determined with addressing the quartiles (Lober, Farrington, Stouthamer-Loeber, \& Van Kammen, 1998) as follow: low aggression level was placed them in the first quartile (Q1), students' aggression level in the second and third quartile (Q2 \& Q3) which is located between $25 \%-75 \%$, are possessing moderate aggression level and the students displayed high scores of aggression level which is higher than moderate category $(>75 \%)$ and put the third group in the fourth quartile (Q4). Therefore majority of students $(n=210)$ revealed moderate aggression level based on Buss and Perry scores, while minority $(n=98)$ of the students displayed high scores of aggression level (Figure 2).

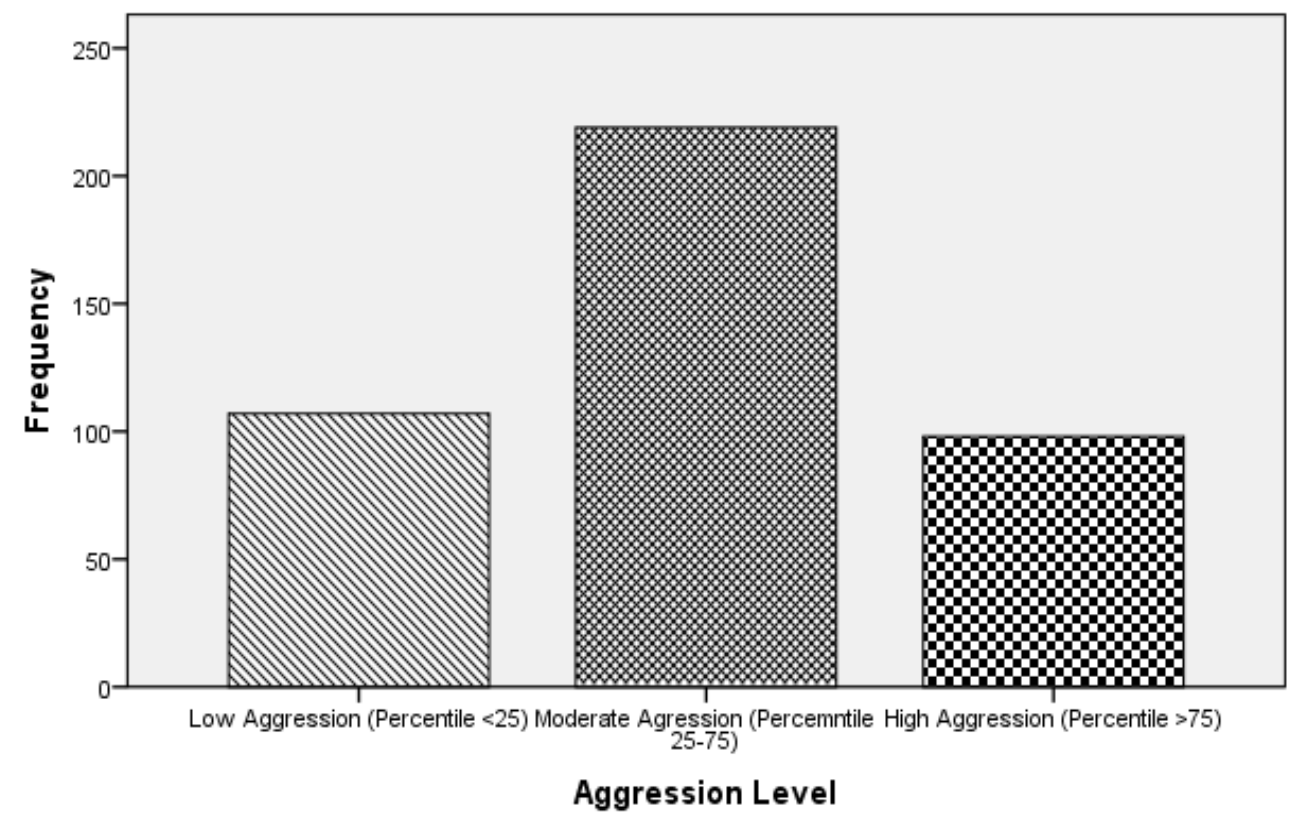

Figure 2. Distributions of Respondents by Aggression Level 


\section{Ml Macrothink}

Table 3 displayed the most favorite students' TV program that indicated the students had a total of 22 favored programs. The findings showed that the most preferred students' TV programs were Amoo Poorang (15.09\%), followed by Ninja Turtles (13.6\%) and Tom and Jerry (12.6\%). The least favorite TV programs according to the students' ideas were Sinderela $(0.94 \%)$ and Red Riding Hood (1.17\%) (Table 3).

Table 3. Students' Favorite TV Program

\begin{tabular}{llllll}
\hline Favorite TV Programs & f & \% & Favorite TV Programs & f & \% \\
\hline Amoopoorang & 64 & 15.09 & Megaman & 9 & 2.12 \\
Fitile & 53 & 12.5 & Superman & 9 & 2.12 \\
Khaleh Shadoneh & 53 & 12.5 & Pink Panter & 8 & 1.88 \\
Tom and Jerry & 49 & 11.55 & Pino Kio & 8 & 1.88 \\
Ninja Turtles & 35 & 8.25 & Brave Boy & 7 & 1.65 \\
Mal Mal & 28 & 6.60 & Pat and Mat & 7 & 1.65 \\
Captain subasa & 17 & 4.00 & Pokemon & 7 & 1.65 \\
Spiderman & 17 & 4.00 & Anne Shirly & 5 & 1.17 \\
Ben Ten & 13 & 3.06 & Mr Bin & 5 & 1.17 \\
Batman & 12 & 2.83 & Red Riding Hood & 5 & 1.17 \\
Shaun the Sheep & 9 & 2.12 & Cinderella & 4 & 0.94 \\
Total & & & & $\mathbf{4 2 4}$ & $\mathbf{1 0 0}$ \\
\hline
\end{tabular}

The findings also showed that the high aggression level was found among the students who reported Pokemon and Batman (100\%), Ben Ten (76.92\%), Captain Tsubasa (76.47\%), Megaman (66.67\%), Superman (66.67\%), and Spiderman (58.82\%) as their favorite TV program respectively (Table 4). Almost all of these programs are belonged to action genre. On the other hand, the least aggression level was appeared among students who reported Red Riding Hood as theirs favorite TV program.

Table 5 presents the program pacing index, and scores for each elements of that index for all 22 children's favorite TV programs, ordered from the highest score to the lowest. The five programs with the most pacing scores were Pokemon (67.08), Ninja Turtle (66.17), Spider Man (64.57), Ben Ten (61.13), and Mega Man (59.81). The five programs with the lower pacing scores were Fitileh (23.86), Cinderella (24.15), Pat and Mat (26.65), Amoo Poorang (28.25), and Mal Mal (30.65). 
Table 4. Comparisons of Students' Aggression Level by Their Favorite TV Programs

\begin{tabular}{llll}
\hline & \multicolumn{3}{c}{ Level of Aggression } \\
\cline { 2 - 4 } Favorite TVPrograms & Low Aggression $(\%)$ & Moderate Aggression $(\%)$ & High Aggression $(\%)$ \\
\hline 1-Pokemon & 0.00 & 0.00 & 100 \\
2-Batman & 0.00 & 0.00 & 100 \\
3-Ben Ten & 0.00 & 23.07 & 76.92 \\
4-Captain subasa & 0.00 & 23.52 & 76.47 \\
5-Megaman & 0.00 & 33.33 & 66.67 \\
6-Superman & 0.00 & 33.33 & 66.67 \\
7-Spiderman & 0.00 & 41.17 & 58.82 \\
8-Ninja Turtles & 11.42 & 45.71 & 42.85 \\
9-Anne Shirly & 20.00 & 60.00 & 20.00 \\
10-Fitileh & 33.96 & 54.71 & 11.32 \\
11-Amoopoorang & 26.56 & 65.62 & 7.81 \\
12-Mal Mal & 10.71 & 82.14 & 7.14 \\
13-Khaleh Shadoneh & 35.846 & 54.49 & 5.66 \\
14-Pink Panter & 12.50 & 87.5 & 0.00 \\
15-Mr Bean & 20.00 & 80.00 & 0.00 \\
16-Tom and Jerry & 44.89 & 55.10 & 0.00 \\
17-Shaun the Sheep & 44.44 & 55.56 & 0.00 \\
18-Pino Kio & 50.00 & 50.00 & 0.00 \\
19-Brave Boy & 57.14 & 42.85 & 0.00 \\
20-Pat and Mat & 57.14 & 42.58 & 0.00 \\
21-Cinderella & 50.00 & 50.00 & 0.00 \\
22-Red Riding Hood & 100 & 0.00 & 0.00 \\
\hline
\end{tabular}

Table 5. Programs' Pacing Indices and Scores in the Individual Pacing Criteria

\begin{tabular}{lllllllll}
\hline & Pacing & Camera & Related & Unrelated & Auditory & Active & Active \\
Programs & Index & Edits(n) & Shifts(n) & Shifts(n) & $\begin{array}{l}\text { Active } \\
\text { Changes(n) }\end{array}$ & Motion(\%) & Music(\%) & Talking(\%) \\
\hline 1-Pokemon & 67.08 & 76 & 31 & 2 & 64 & 60 & 77 & 74 \\
2-Ninja Turtles & 66.17 & 110 & 22 & 2 & 42 & 59 & 97 & 81 \\
3-Spider Man & 64.57 & 131 & 28 & 1 & 28 & 55 & 97 & 85 \\
4-Benten & 61.13 & 104 & 28 & 1 & 45 & 60 & 67 & 66 \\
5-Megaman & 59.81 & 79 & 23 & 3 & 52 & 28 & 76 & 76 \\
6-Captain subasa & 57.53 & 75 & 17 & 3 & 44 & 33 & 82 & 80 \\
7-Superman & 54.63 & 117 & 21 & 0 & 31 & 72 & 90 & 40 \\
8-Batman & 49.35 & 75 & 35 & 2 & 37 & 43 & 11 & 23 \\
9-Red Riding Hood & 44.52 & 75 & 11 & 1 & 54 & 20 & 63 & 85 \\
10-Brave Boy & 40.87 & 69 & 15 & 2 & 24 & 23 & 40 & 62 \\
11-Khaleh Shadoneh & 39.79 & 40 & 2 & 5 & 12 & 4 & 40 & 77 \\
12-Anneshirly & 36.99 & 72 & 12 & 1 & 18 & 16 & 73 & 63 \\
13-Pinocchio & 34.77 & 50 & 8 & 1 & 29 & 32 & 87 & 66 \\
14- Pink Panther & 34.42 & 63 & 25 & 0 & 7 & 23 & 96 & 12 \\
15-Shaun the Sheep & 32.86 & 63 & 10 & 1 & 12 & 40 & 67 & 8 \\
16-Tom and Jery & 32.21 & 69 & 5 & 1 & 12 & 25 & 95 & 18 \\
17-Mr Bean & 31.54 & 97 & 12 & 1 & 16 & 9 & 45 & 25 \\
18-Mal Mal & 30.68 & 55 & 11 & 0 & 21 & 10 & 70 & 75 \\
19Amoopoorang & 28.25 & 74 & 2 & 0 & 38 & 10 & 20 & 90 \\
20-Pat and Mat & 26.65 & 61 & 7 & 1 & 12 & 11 & 83 & 3 \\
21-Cinderella & 24.15 & 31 & 3 & 0 & 13 & 9 & 80 & 75 \\
22-Fitileh & 23.86 & 38 & 2 & 1 & 10 & 11 & 26 & 83 \\
\hline
\end{tabular}




\section{Ml Macrothink}

Journal of Sociological Research

ISSN 1948-5468

2019, Vol. 10, No. 2

For the purpose of looking for whether there is a significant difference in mean pacing score among various level of aggression among the students, a median split was done on pacing score to create the fast-paced and slow-paces programs. The results indicated that most of the aggressive students favored on fast-paced TV programs (84.69\%). On the other hand, most of the students categorized in low (64.48\%) and moderate aggression level (61.64\%), were interested in TV programs with slow-paced. The findings showed a significant association between the students' aggression level and TV program pacing $(\mathrm{p}<0.001)$ (Table 6$)$. Therefore, based on these findings, the TV programs that were categorized as fast-paced, were the favorite programs of those with the highest aggression scores while those placed in slow-paced programs, had the favorite programs of the lowest aggression scores.

Table 6. Students' TV Favorite Program Pacing by Different Aggression Level ( $n=424)$

\begin{tabular}{|c|c|c|c|c|c|c|c|c|}
\hline & \multirow{3}{*}{ Aggression level } & \multicolumn{4}{|c|}{ Pacing } & \multirow{3}{*}{ Total } & \multirow{3}{*}{$\chi^{2}$} & \multirow{3}{*}{ Sig. } \\
\hline & & \multicolumn{2}{|l|}{ Slow } & \multicolumn{2}{|c|}{ Fast } & & & \\
\hline & & $\mathrm{n}$ & $\%$ & $\mathrm{n}$ & $\%$ & & & \\
\hline & Low (Percentile <25\%) & 69 & 64.48 & 38 & 35.51 & 107 & 67.65 & .000 \\
\hline Students' & Moderate (Percentile 25-75\%) & 135 & 61.64 & 84 & 38.35 & 219 & & \\
\hline Aggression & High (Percentile $>75 \%)$ & 15 & 15.30 & 83 & 84.69 & 98 & & \\
\hline Level & Total & 219 & & 205 & & 424 & & \\
\hline
\end{tabular}

In order to test the hypothesis of this study concerning the relationship between TV program pacing and the students' aggression level, a Spearman correlation analysis was conducted. The results showed a significant relationship $(\mathrm{p}<0.05)$ between the TV program pacing and students' aggression level. The significant relationships also presented for all sub-scales of aggression, that is, physical aggression, verbal aggression, anger, and hostility (Table 7). The results indicated a significant moderate and positive relationship between TV program pacing and students' aggression level for total aggression ( $\mathrm{rs}=.388, \mathrm{p}<0.01)$, physical aggression $(\mathrm{rs}=.383, \mathrm{p}<0.01)$, anger $(\mathrm{rs}=.331, \mathrm{p}<0.01)$, and hostility $(\mathrm{rs}=.306, \mathrm{p}<0.01)$ and a low and positive relationship between TV program pacing and students' aggression level for verbal aggression $(\mathrm{rs}=.274, \mathrm{p}<0.01)$. 


\section{Macrothink}

Journal of Sociological Research

ISSN 1948-5468

2019, Vol. 10, No. 2

Table 7. Relationship between TV Program Pacing and Students' Aggression Level by Different Components of Aggression ( $n=424)$

\begin{tabular}{|c|c|c|c|c|c|c|c|c|}
\hline & & & $\begin{array}{l}\text { Total } \\
\text { Aggression }\end{array}$ & Physical & Verbal & Anger & Hostility & $\begin{array}{l}\text { Pacing } \\
\text { score }\end{array}$ \\
\hline \multirow[t]{18}{*}{ Spearman's rho } & Total & Correlation & -- & $.876^{* *}$ & $.830 * *$ & $.838 * *$ & $.905 * *$ & $.388 * *$ \\
\hline & Aggression & Coefficient & & & & & & \\
\hline & & Sig. & -- & .000 & .000 & .000 & .000 & .000 \\
\hline & Physical & Correlation & & -- & $.645^{* *}$ & $.694 * *$ & $.682 * *$ & $.383^{* *}$ \\
\hline & Aggression & Coefficient & & & & & & \\
\hline & & Sig. & & -- & .000 & .000 & .000 & .000 \\
\hline & Verbal & Correlation & & & -- & $.586 * *$ & $.720 * *$ & $.274 * *$ \\
\hline & Aggression & Coefficient & & & & & & \\
\hline & & Sig. & & & -- & .000 & .000 & .000 \\
\hline & Anger & Correlation & & & & -- & $.698 * *$ & $.331 * *$ \\
\hline & & Coefficient & & & & & & \\
\hline & & Sig. & & & & -- & .000 & .000 \\
\hline & Hostility & Correlation & & & & & -- & $.306^{* *}$ \\
\hline & & Coefficient & & & & & & \\
\hline & & Sig. & & & & & -- & .000 \\
\hline & Pacing & Correlation & & & & & & -- \\
\hline & score & Coefficient & & & & & & \\
\hline & & Sig. & & & & & & -- \\
\hline
\end{tabular}

*. $\mathrm{P}<.05 \quad * * . \mathrm{P}<.01$

A linear regression analysis was conducted to evaluate the association of TV program pacing with the children's aggression level. The results indicated that there is a significant relationship $(p<0.001)$ between the pacing scores of the students' favorite television programs and tendency of the students to behave aggressively (Figure 3). This finding indicated that the students who preferred to watch the fast paced TV programs, more likely intended to behave aggressively. 


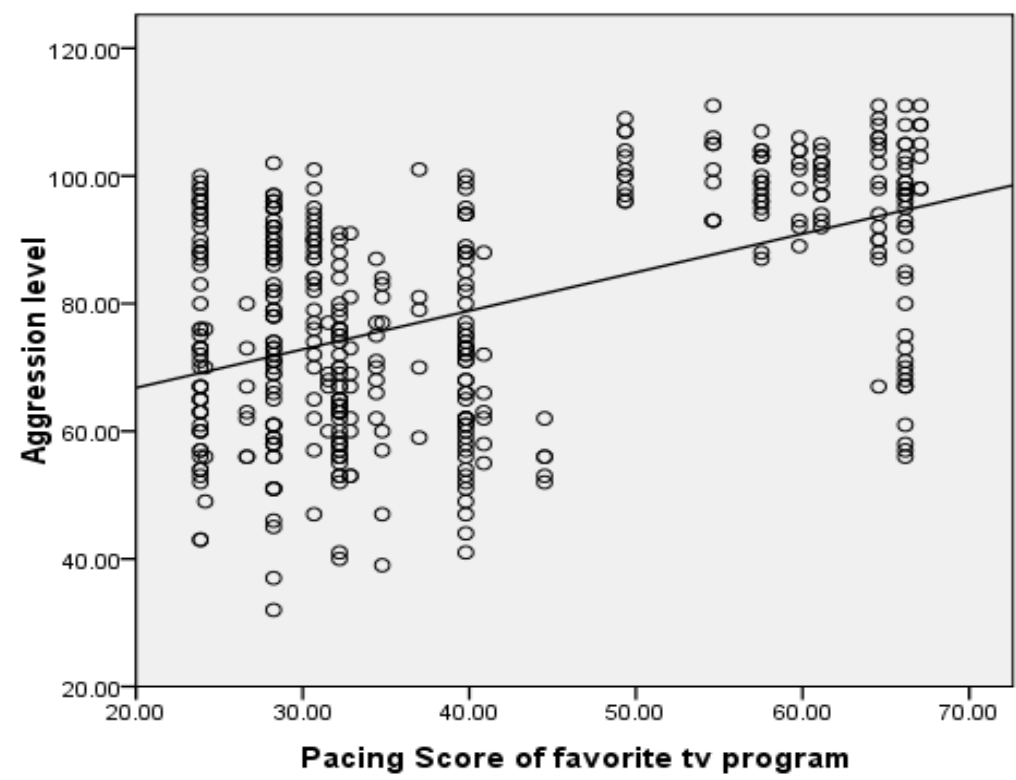

O Observed

Figure 3. Association of Students' Preferred TV Program Pacing Score with their Aggression Level

\section{Discussion}

This study explored the relationship between television program pacing and aggression level among the primary students. Results illustrated that $23 \%$ of respondents showed high and moderate level of aggression in their behavior. Najafi, Foladchang, Alizadeh and Mohamadifar (2009), in their study, showed that $17.8 \%$ of the elementary students displayed behavioral violence in the South-West of Iran. According to the findings, the most favorite students' TV programs were Amoo Poorang followed by Fetileh and Khaleh Shahdooneh, Tom and Jery and Ninja Turtles respectively. The least favorite TV programs were Sinderela. In the same line, Fallahnezhad (2012) in her national survey reported that the most favorite TV program of the Iranian children were Amoopoorang, Khaleh Shadoneh, Fitile, Tom and Jerry, Pink Panter and Mal Mal respectively. She also showed that children were interested in watching programs such as Superman, Batman, Spiderman, Ninja Turtles, Captain Subasa, Ben Ten and Pokemon through satellite.

The five programs with the most pacing scores were Pokemon, Ninja Turtle, Spider Man, Ben Ten and Mega Man respectively which marked as fast paced program. Consistently McCollum and Bryant (2003) also found these programs in category of fast paced programs. The findings of the current study illustrated that higher level of aggression in all domains was found in some favorite children's animation genre coded as Action adventure, Action, Sports, and Horror. The most favorite genre in children's television is animation (Nazari et al., 2013). A variety of visual and auditory traits that gain children's attention was studied by Alwitt, Anderson, Lorch and Levin, (1980). Their study revealed that animation has powerful eliciting impacts on children's attention; although, animations have been often criticized for 
being fast-paced. Almost 700 Japanese children in Japan were taken to the hospital after viewing an episode of Pokemon which is a famous animation program in 1997 (McCollum \& Bryant, 2003). The particular episode contained a scene with red, white, and blue flashes in midst of an explosion of other colors. The present study also found Pokemon as the fastest paced program that illustrated the high level of aggression among the primary students who reported that the program was as their most favorite TV programs. The pacing of Pokemon ranked the first among 22 programs among the children favorite TV programs, and ranked in the top five in the following categories: camera edits, auditory changes, action motion, and active talking. These programs also were belong to fast-paced programs that favored by students who displayed high aggression behavior. The research hypothesis supported where the finding revealed that the children's favorite TV pacing scores were significantly and positively associated with the aggression level $(\mathrm{p}<0.05)$. Huston, Bickham, Lee and Wright (2007) maintain researchers have compared the formal traits of live action programs with animation programs with variables such as rapid action, music, noise, tempo, visual tricks, and human and non-human conversations. Animations reveal higher frequencies in comparison with live programs for all of the perceptually important traits. Animation programs have greater rate of new scene introductions, higher levels of rapid action, and rapid tempo of familiar cut shifts in comparison with live action programs. In a same line, this study reemphasized that animation programs have faster pace in comparison with live action programs.

The limited capacity theory of mediated message processing posits that people have a limited number of mental resources available for processing media messages (Lang, 2000). Specific characteristics of messages, such as the pacing and violent content are considered to influence how these resources are assigned, and thus, how people process and keep information about these messages in memory. These characteristics may also influence the people's judgments about the relative influence of these messages on one's own self and others. The limited capacity theory posits that when viewers watch television, they are engaged in three subprocessing of information that involves encoding, storage, and retrieval processes of messages. As Lang (1990) argues, viewers continually paid attention to messages in a television viewing context, encode those messages into short-term memory boxes, and keep information. Simultaneously, viewers retrieve information stored previously to associate it with new messages and keep the newly modified messages again. According to the theory, viewers' limited capacity of processing information is distributed across the three processes. The distribution of the limited capacity is sometimes determined by the attributes of messages such as the content and formats like special effects, and by the controlled process triggered by the viewer's interests, goals, and motivations (Lang, 2000). Information processing suggests that formal features of television such as cuts, movement, and sound changes increase attention (Lang, 1990; 1991).

Pacing has been mentioned to have some impacts on children. Christiakis (2009) maintains that fast pace programs perhaps could help stimulate brain development. Other scholars also have demonstrated the significant relationships between television programs paced and children's attentive behavior (Anderson, Field, Collins, Lorch, \& Nathan 1985; Zimmerman 
\& Christakis, 2005). According to Lillard and Peterson (2011), children's Executive Function (EF) varied after viewing a fast-paced cartoon TV program, an educational cartoon TV show, or drawing. After viewing the fast-paced cartoon, 4-year-old children performed significantly worse on EF tasks in comparison with children in the drawing condition. Researchers identified that children allocated to watch slow-paced programs committed considerably more errors in attention tests than those who watched fast-paced shows. Therefore, these studies reveal that fast-pacing show does not necessarily impact children's behavior negatively. In other words, under specific conditions, it seems that fast-pacing programs may increase the attention and recall power (Cooper, Uller, Pettifer, \& Stolc, 2009).

Slater, Henry, Swaim, and Anderson (2003) studied the selective exposure in 3100 students of grade 8 . The finding showed that adolescents were interested in violent movies, especially with action genres. The researchers have recognized lesson similarities that were learnt by children and adult programming. These lessons included: 1) the level of violence among bad and good characters is almost similar. 2) For solving the problems, aggression behavior on television is used 3) television hero actively utilizes the violence to solve dilemmas; and finally 4) since in violence acts, all victims get well entirely; therefore, the violence is not considered harmful (Rosenkoetter, Rosenkoetter, Ozretich, \& Acock, 2004; Rosenkoetter, Rosenkoetter, \& Acock 2009). An excellent example of this is the episodic cartoon "Teenage Mutant Ninja Turtles" which also was one of the most favorite TV programs based on the present research respondents' point of view. These specific mutant tortoises can walk, move, talk, act, think, and reason the same as human beings. They are shown as heroes and overcome their enemies using karate moves and weapons. Here, the message is these four tortoises are clearly good guys, but their actions are somehow similar to the evil that they eliminate. Violence is seen as justifiable in this type of representation and children absorb it like a sponge.

\section{Conclusion}

The present study concluded that a student is interested in participating in aggressive roles or acts after watching programs contained images of fighting or violence in nature. Furthermore, watching TV programs with fast-pace could possibly have an impact on their behavior which leads them to act aggressively. These results extend the research by revealing that indirect aggression is also portrayed very often on television and affects aggressive behaviors on people, especially on children. In conclusion, the present study gives support to the fact that the television programs content, specifically its pacing index, is very significant in forming the children's behaviors. Focusing on pacing as an important factor in producing media programs could be helpful for decision makers. One major element in efficient communication is the production and convey of precise and efficient messages through the mass media. The findings of the present study proposed the need for paying more attention to the production of children's programs to protect them from aggressive behaviors and interventions in violence-exposed children to decrease the negative outcomes. Eventually, further study is required to investigate the relationships between pacing and some other 
dependent variables such as learning process, social interaction, and problem solving.

\section{Disclosure statement}

No potential conflict of interest was reported by the authors.

\section{References}

Alwitt, L. F., Anderson, D. R., Lorch, E. P., \& Levin, S. R. (1980). Preschool children's visual attention to television. Human Communication Research, 7, 52-67. https://doi.org/10.1111/j.1468-2958.1980.tb00550.x

Anderson, C. A., \& Dill, K. E. (2000). Video games and aggressive thoughts, feelings, and behavior in the laboratory and in life. Journal of Personality and Social Psychology, 78, 772-790. https://doi.org/10.1037/0022-3514.78.4.772

Anderson, C. A., Berkowitz, L., Donnerstein, E., Huesmann, L. R., Johnson, J. D., Linz, D., Malamuth, N. M., \& Wartella, E. (2003). The influence of media violence on youth. American Psychological Society, 4(3), 81-110. https://doi.org/10.1111/j.1529-1006.2003.pspi_1433.x

Anderson, D. R., Field, D. E., Collins, P. A., Lorch, E. P., \& Nathan, J. G. (1985). Estimates of young children's time with television: A methodological comparison of parent reports with time-lapse video home observation. Child Development, 56(5), 1345-1357. https://doi.org/10.2307/1130249

Anderson, D. R., \& Hanson, K. G. (2009). Children, media, and methodology. American Behavioral Scientist, 52(8), 1204-1219. https://doi.org/10.1177/0002764209331542

Bandura, A., Ross, D., \& Ross, S. A. (1963). Imitation of film-mediated aggressive models. Journal of Abnormal and Social Psychology, 66(7), 3-11. https://doi.org/10.1037/h0048687

Bendersky, M., Bennett, D., \& Lewis, M. (2006). Aggression at age 5 as a function of prenatal exposure to cocaine, gender, and environmental risk. Journal of Pediatric Psychology, 31(1), 71-84. https://doi.org/10.1093/jpepsy/jsj025

Bensley, L., \& Eenwyk, J. (2001). Video games and real-life aggression: review of the literature. Journal of Adolescent Health, 29(4), 244-257. https://doi.org/10.1016/S1054-139X(01)00239-7

Bickham, D. S., Wright, J. C., \& Huston, A. C. (2001). Attention, comprehension, and the educational influences of television. In D.G. Singer \& J.L. Singer (Eds.), Handbook of children and media. Thousand Oaks, CA: Sage Publications.

Blumer, H. (1933). Movies and Conduct. New York: Macmillan. 
Broidy, L., Tremblay, R., Brame, B., Fergusson, D., Horword, J., \& Laird, R. (2003). Developmental trajectories of childhood disruptive behaviors and adolescent delinquency: A six-site, cross-national study. Developmental Psychology, 39, 222-245. https://doi.org/10.1037/0012-1649.39.2.222

Buchanan, A. M., Gentile, D. A., Nelson, D., Walsh, D. A., \& Hensel, J. (2002), August). What goes in must come out: Children's media violence consumption at home and aggressive behaviors at school. Paper presented at the International Society for the Study of Behavioural Development Conference, Ottawa, Ontario, Canada.

Buss, A. H., \& Perry, M. P. (1992). The aggression questionnaire. Journal of Personality and Social Psychology, 63, 452-459. https://doi.org/10.1037/0022-3514.63.3.452

Christiakis D, A. (2009). The effects of infant media usage: what do we know and what $\begin{array}{llll}\text { should we learn? Acta Paediatrica, } & \text { 98, }\end{array}$ https://doi.org/10.1111/j.1651-2227.2008.01027.x

Cohen, J. (1960) A coefficient of agreement for nominal scales. Educational and Psychological Measurement, 20, 37-46. https://doi.org/10.1177/001316446002000104

Cooper, N. R., Uller, C., Pettifer, J., \& Stolc, F. C. (2009). Conditioning attentional skills: Examining the effects of the pace of TV editing on children's attention. Acta Paediatrica, 98(10), 1651-1655. https://doi.org/10.1111/j.1651-2227.2009.01377.x

Emory, H.W., \& Gridina, N. (2000). Media in the home: The fifth annual survey of parents and children. Philadelphia: The Annenberg Public Policy Center of University of Pennsylvania. Survey Series, No. 7.

Fallahnezhad, Z. (2012). Survey on TV programs among children aged 5 to 10 in 32 cities in Iran. IRIB Research Centre Journal, 72, 37-45.

Ferguson C. J. (2015). Does Media Violence Predict Societal Violence? It Depends on What You Look at and When. Journal of Communication, 65(1), E1-E22. https://doi.org/10.1111/jcom.12129

Fox, J. R., Park, B., \& Lang, A. (2007). When Available Resources Become Negative Resources: The Effects of Cognitive Overload on Memory Sensitivity and Criterion Bias. Communication Research, 34(3), 277-296. https://doi.org/10.1177/0093650207300429

Funk, J. B., Baldacci, H. B., Pasold, T., \& Baumgardner, J. (2004). Violence exposure in real-life, video games, television, movies, and the internet: is there desensitization? Journal of Adolescence, 27, 23-39. https://doi.org/10.1016/j.adolescence.2003.10.005

Gerevich, J, Bácskai, E., \& Czobor, P. (2007). The generalizability of the Buss-Perry Aggression Questionnaire. International Journal of Methods in Psychiatrics Research, 16(3), 124-36 https://doi.org/10.1002/mpr.221

Grimes, T., \& Bergen, L. (2008). The epistemological argument against a causal relationship between media violence and sociopathic behavior among psychologically well viewers. 
American Behavioral Sciences, $\quad$ 51(8), $\quad$ 1137-1154. https://doi.org/10.1177/0002764207312008

Hinton, W. J., Sheperis, C., \& Sims, P. (2003). Family-based approaches to juvenile delinquency: A review of the literature. The Family Journal, 11(2), 167-173. https://doi.org/10.1177/1066480702250156

Daigle, L. E., Cullen, F.T., \& Wright, J. P. (2007). Gender differences in the predictors of juvenile delinquency: Assessing the generality-specificity debate. Youth Violence and Juvenile Justice, 5(3), 254-286. https://doi.org/10.1177/1541204007301289

Huston, A., Bickham, D., Lee, J., \& Wright, J. (2007). From attention to comprehension: How children watch and learn from television in N. Pecora, J. Murray and E. Wartella (Eds.), Children and Television: Fifty Years of Research (pp.41-63). Mahwah, New Jersey: Lawrence Erlbaum.

José Martínez, G. I., Prieto, M. D., \& Farfán, J. (2006). Childhood and violence in advertising: A current perspective. The International Communication Gazette, 68(3), 269-287. https://doi.org/10.1177/1748048506063765

Kang, Y., Wright, J. C., \& Huston, M. (2006). The attentional mechanism of message sensation value: Interaction between message sensation value and argument quality on message effectiveness. Communication Monographs, 73(4), 351-378. https://doi.org/10.1080/03637750601024164

Kupchik, A., \& Bracy, N. L. (2009). The news media on school crime and violence: Constructing dangerousness and fueling fear. Youth Violence and Juvenile Justice, 7(2), 136-155. https://doi.org/10.1177/1541204008328800

Lang, A. (1990). Involuntary attention and physiological arousal evoked by structural features and emotional content in T.V. commercials. Communication Research, 17, 275-299. https://doi.org/10.1177/009365090017003001

Lang, A. (1991). Emotion, formal features, and memory for televised Political advertisements. In F. Biocca (Ed.), Television and political advertising (Vol. 1, pp. 221-244). Hillsdale, NJ: Lawrence Erlbaum, Associates.

Lang, A. (2000). The limited capacity model of mediated message processing. Journal of Communication, 50, 46-70. https://doi.org/10.1111/j.1460-2466.2000.tb02833.x

Lang, A., Bolls, P., Potter, R., \& Kawahara, K. (1999). The effects of production pacing and arousing content on the information processing of television messages. Journal of Broadcasting \& Electronic Media, 43, 451-475. https://doi.org/10.1080/08838159909364504

Lang, A., Schwartz, N., Chung, Y., \& Lee, S. (2004). Processing substance abuse messages: Production pacing, arousing content, and age. Journal of Broadcasting and Electronic Media, 48(1), 61-88. https://doi.org/10.1207/s15506878jobem4801_4 


\section{$\Lambda$ Macrothink}

Journal of Sociological Research

ISSN 1948-5468

2019, Vol. 10, No. 2

Lang, A., Zhou, S., Schwartz, N., Bolls,. P. D., \& Potter, R. F. (2000). The effects of edits on arousal, attention, and memory for television messages: When an edit is an edit, can an edit be too much? Journal of Broadcasting \& Electronic Media, 44(1), 94-109. https://doi.org/10.1207/s15506878jobem4401_7

Liebert, R. M., \& Sprafkin, J. (1988). The early window: Effects of television on children and youth ( $3 \mathrm{~d}$ Ed.). New York: Pergamon.

Lillard, A. S., \& Peterson, J. (2011). The immediate impact of different types of television on young children's executive function. Pediatrics, 128(4), 644-649. https://doi.org/10.1542/peds.2010-1919

Lober, R., Farrington, D. P., Stouthamer-Loeber, M., \& Van Kammen, W. B. (1998). Antisocial behavior and mental health problems. Mahwah, NJ: Lawrence Erlbaum Associates. https://doi.org/10.4324/9781410602930

Macnamara, J. (2005). Media content analysis: Its uses; benefits and best practice methodology. Asia Pacific Public Relations Journal, 6(1), 1-34.

McCollum, J. F., \& Bryant, J. (2003). Pacing in children's television programming. Mass Communication \& Society, 6, 115-136. https://doi.org/10.1207/S15327825MCS0602_1

Mohammadi, N. (2007). Preliminary evaluation of psychometric indices of Buss-Perry Aggression Questionnaire. Journal of Social Sciences and Humanities of Shiraz University, 25(4), 135-151.

Moses, A. M. (2008). Impacts of television viewing on young children's literacy development in the USA: A review of the literature. Journal of Early Childhood Literacy, 8(1), 67-102. https://doi.org/10.1177/1468798407087162

Murray, J. P. (2008). Media Violence: The effects are both real and strong. American Behavioral Scientist, 51(8), 1212-1230. https://doi.org/10.1177/0002764207312018

Najafi, M., Foladchang, M., Alizadeh, H., \& Mohamadifar, M. (2009). The prevalence of attention deficit hyperactivity, conduct disorder, and oppositional defiant disorder of elementary school aged children. Journal of Research on Exceptional Children, 3, 239-254.

Nazari, M. R., Hassan, M. D. S., Hj, Osman, M. N., Parhizkar, S., \& Yasin. M. (2013). Children Television Viewing and Antisocial Behavior: Does the Duration of Exposure Matter? Journal of Sociological Research. 4(1), 207-217. https://doi.org/10.5296/jsr.v4i1.3115

Nazari, M. R., Hassan, M. D. S., Hj, Osman, M. N., Yasin. M., \& Parhizkar, S. (2013). Influence of Television Programs Genre on Violent Behaviour among Young Children. British Journal of Education, Society \& Behavioural Science, 3(4), 519-531 https://doi.org/10.9734/BJESBS/2013/4765

Nazari, M. R., Hasbullah, A. H., Parhizkar, S., Shirazi, A. R., \& Marioriad, H. (2009). The 
impact of visuals: Using television program to transform environmental health concepts to people. Journal of Applied Sciences. 9(14), 2616-2624. https://doi.org/10.3923/jas.2009.2619.2624

Nunnally J. C. (1978). Psychometric theory. New York: McGraw-Hill.

Potter, R. F., \& Callison, C. (2000). Sounds exciting! The effects of auditory complexity on listeners' attitudes and memory for radio promotional announcements. Journal of Radio Studies, 7, 29-51. https://doi.org/10.1207/s15506843jrs0701_5

Potter, R. F., \& Choi, J. (2006). The effects of auditory structural complexity on attitudes, attention, arousal, and memory. Media Psychology, 8(4), 395-419. https://doi.org/10.1207/s1532785xmep0804_4

Reingle, J. M., Jennings, W. G., Maldonado-Molina, M. M., Piquero, A. R., \& Canino, G. (2011). Investigating the role of gender and delinquency in exposure to violence among puertorican youth. Journal of Contemporary Criminal Justice, 27(3), 361-377. https://doi.org/10.1177/1043986211412571

Rosenkoetter, L. I., Rosenkoetter, S. E., Ozretich, R. A., \& Acock, A. C. (2004). Mitigating the harmful effects of violent television. Journal of Applied Developmental Psychology, 25, 25-47. https://doi.org/10.1016/j.appdev.2003.11.005

Rosenkoetter, L. I., Rosenkoetter, S. E., \& Acock, A. C. (2009). Television violence: An intervention to reduce its impact on children. Journal of Applied Developmental Psychology, 30, 381-397. https://doi.org/10.1016/j.appdev.2008.12.019

Samani, S. (2008). Study of reliability and validity of the buss and perry's aggression questionnaire. Iranian Journal of Psychiatry and Clinical Psychology, 13(4), 359-365.

Savage, J. (2008). The role of exposure to media violence in the etiology of violent behavior. American Behavioral Scientist, $\quad$ 51(8), $1123-1136$. https://doi.org/10.1177/0002764207312016

Savage. J., \& Yancey, C. (2008). The effects of media violence exposure on criminal aggression: a meta-analysis. Criminal Justice and Behavior, 35(6), 772-791. https://doi.org/10.1177/0093854808316487

Slater, M. D., Henry, K., Swaim, R. C., \& Anderson, L. L. (2003). Violent media content and aggressiveness in adolescents, a downward spiral model. Communication Research, 30(6), 713-736. https://doi.org/10.1177/0093650203258281

Vande berg, L. R., Wenner, L. A., \& Gronbeck, B. E. (2004). Media literacy and television criticism: Enabling an informed and engaged citizenry. American Behavioral Scientist, 48(2), 219-228. https://doi.org/10.1177/0002764204267266

Villani, S. (2001). Impact of media on children and adolescents: A 10-year review of the research. American Academy of Child and Adolescent Psychiatry, 40(4), 392-401. https://doi.org/10.1097/00004583-200104000-00007 
Wilson, B. J., Smith, S. L., Potter, W. J., Kunkel, D., Linz, D., \& Colvin. (2002). Violence in children's television programming: Assessing the risks. Journal of Communication, 52(1), 5-35. https://doi.org/10.1111/j.1460-2466.2002.tb02531.x

Wright, J. C., Huston, A. C., Ross, R. P., Calvert, S. L., Rolandelli, D., \& Weeks, L. A. (1984). Pace and continuity of television programs: Effects on children's attention and comprehension. Developmental Psychology, 20(4), 653-66638. https://doi.org/10.1037/0012-1649.20.4.653

Yoon, K., Bolls, P. D., \& Muehling, D. D. (1999). The moderating role of involvement and the effects of content arousal and pace on viewers' attitudes toward the ad. Media Psychology, 1, 331-352. https://doi.org/10.1207/s1532785xmep0104_3

Zegers, M., Bruijne, M. C., Wagner, C., Groenewegen, P. P., Wal, G., \& Vet, H. C. (2010). The inter-rater agreement of retrospective assessments of adverse events does not improve with two reviewers per patient record. Journal of Clinical Epidemiology, 63, 94-102. https://doi.org/10.1016/j.jclinepi.2009.03.004

Zimmerman, F. J., \& Christakis, D. A. (2005). Children's television viewing and cognitive outcomes: A longitudinal. Pediatrics analysis of national data. Archives of Pediatrics and Adolescent Medicine, 159(7), 619-625. https://doi.org/10.1001/archpedi.159.7.619

Zimmerman, F. J., \& Christakis, D. A. (2007). Associations between content types of early media exposure and subsequent attention problems, Pediatrics, 120, 986-992. https://doi.org/10.1542/peds.2006-3322

\section{Copyright Disclaimer}

Copyright for this article is retained by the author(s), with first publication rights granted to the journal.

This is an open-access article distributed under the terms and conditions of the Creative Commons Attribution license (http://creativecommons.org/licenses/by/3.0/). 